\title{
Selection of Gamma Irradiation Dose for Sterilising Eye Make up Preparations
}

\author{
Z.E. EL-Bazza, S.Y. Eltablawy ${ }^{*}$, A.S.E. Mohamed and H. \\ A. Nasser \\ Department of Drug Radiation Research, National Centre for \\ Radiation Research and Technology, A.E.A., Cairo, Egypt.
}

\begin{abstract}
T N THE PRESENT study, radioresistant bacterial strains isolated from the dried mixed populations of bacteria of, eye make up preparations were used. The mixed population of bacterial strains from eye shadow, eye mascara and eye liner, survived the radiation doses of 5-14 kGy, 5-6 kGy and 4-11 kGy, respectively. Dose survival curves of the radioresistant bacterial strains exhibited exponential response, except Bacillus cereus which showed non exponential response towards gamma radiation. The $\mathrm{D}_{10}$ values were in the range of 0.7-1.8 kGy, 0.8-1.0 kGy and 0.7-1.4 kGy for the strains from eye shadow, eye mascara and eye liner, respectively. The sterilization doses for the eye make up products were determined from the dose response curves. The maximum sterilization doses were found to be $16.0,8.3$ and $12.3 \mathrm{kGy}$ for sterilization of the eye make up products at the same mentioned order.
\end{abstract}

Keywords : Eye make up preparations, Mixed population, Gamma radiation, Sterilization.

The need to control microbiological contamination of all products for human use and consumption, has been of considerable concern to manufacturers. Modern food, pharmaceutical, cosmetic and toiletry industries strive for high microbiological standards to protect their products from spoilage on the one hand, and their consumers from infection, on the other hand. Unlike foodstuffs, which are usually kept refrigerated or thrown away after a few days, a much longer shelf life is expected for personal care products (Razem et al., 2003).

A standard hygiene control system is vital in order to lower the level of contamination to safe level. Ionizing radiation is used for decontamination purposes. The pharmaceutical industry has been leading the way in the change of attitudes from the quality control (QC) to the quality assurance (QA) approach. Treatment by irradiation is a particularly suitable measure to be integrated into a comprehensive (QA) approach in the processing of biological materials for microbial safety. Ionizing radiation is a universal, nonselective biocidal agent; it acts on all forms of life, in all parts of an irradiated volume; it can be delivered in precise portions of dose; and there is a well-defined relationship between the degree of killing of microorganism and irradiation dose (Clegg, 1988 and Razem, 2001).

*Correspondance email: dr.seham@hotmail.com 
The most important consideration in selecting a particular sterilization dose is the destruction of microorganisms with no alteration in the product properties. Thus knowledge on the type and number of organisms per unit product prior to sterilization is of considerable value (Roushdy et al., 1999).

The present study was elucidated to determine the radiation doses for sterilizing eye make up preparations sold in Egypt.

\section{Materials and Methods}

\section{Microorganisms}

A total of seventy seven (77) bacterial contaminants were previously isolated from eye make up products obtained from the local market (38 bacterial isolates from eye shadow samples, 23 from eye mascara samples and 16 from eye liner samples) in our previous study (El Bazza et al., 2009). The bacterial isolates were purified and identified. They were maintained on nutrient agar, stored at $4^{\circ} \mathrm{C}$ and subcultured monthly on the same medium.

\section{Eye make up samples}

A total of fifty seven (57) eye make up samples were collected from the local market and bacterial contamination was reported in our previous study (El-Bazza et al., 2009): 26 eye shadow samples manufactured by 6 different companies (A, C, D, E , F and G ), 20 eye mascara samples manufactured by 5 different companies (A, H, I, J and K) and 11 eye liner samples manufactured by 3different companies(A, H and I).

\section{Chemicals}

Peptone, Lab-Lemco (Oxoid), Yeast extract (BBL) and Agar-Agar (Difco) were used. Other chemicals used in the present study were of the reagent grade.

\section{Gamma irradiation facility}

The Cobalt-60 source (Indian Gamma cell 4000A) located at the National Centre for Radiation Research and Technology (NCRRT), Nasr City, Cairo, Egypt was utilized as the radiation resource in the present investigation. The dose rate was $1.00424 \mathrm{kGy} / \mathrm{sec}$ at the time of experiments.

\section{Dose survival curve of the bacterial organisms to gamma radiation}

The bacterial strains isolated in a pervious study from samples representing each manufacturing company were heavily cultured on nutrient agar plates and the grown colonies were used to prepare test pieces according to Christensen \& Holm (1964) and Christensen \& Kristensen (1981). A twenty four hour of each bacterial culture was used for surface inoculation on nutrient agar plates. After incubation at $35 \pm 2{ }^{\circ} \mathrm{C}$ for $48 \mathrm{hr}$, the bacteria was scrapped off by using sterile glass slide and transferred into a small porcelain mortar, horse serum broth was added dropwise to the mortar and then homogenized to have a thick suspension. The resulting dense suspension of microorganisms was distributed as separate spots, each $20 \mu \mathrm{l}$, on sterile polyethylene foil (pre sterilized at $25 \mathrm{kGy}$ ) and dried at room temperature on a laminar air bench. The dried spots were then 
covered with another sterile polyethylene sheet and the two layers were heatsealed in squares each containing one spot (using Impulse sealer Tisw 300 waat 430-450 W, Tiwan). The test pieces, in triplicates, were exposed at room temperature to gamma radiation doses ranging from 2.0 to $15.0 \mathrm{kGy}$.

\section{Isolation of the radioresistant bacterial organisms}

The irradiated test pieces were aseptically removed from the polyethylene bags and each was transferred into $10 \mathrm{ml}$ of sterile saline $\{0.89(\mathrm{w} / \mathrm{v}) \%$ $\left.\mathrm{NaCl} / \mathrm{H}_{2} \mathrm{O}\right\}$, shaken vigorously and ten fold serial dilutions in the same solution were made. Aliquots of $0.1 \mathrm{ml}$ from the homogenous suspension were used for surface inoculation on nutrient agar plates (peptone, $5 \mathrm{~g}$; sodium chloride, $1.0 \mathrm{~g}$; yeast extract, 3.0g, Lab Lemco, 1.0g; Agar, $20 \mathrm{~g}$ and distilled water, $1000 \mathrm{ml}$ ). The plates were incubated at $35 \pm 2^{\circ} \mathrm{C}$ and examined daily for a maximum period of one week and the growth was examined macroscopically. The bacterial isolates from each type of the eye make up product, which could survive the highest radiation doses under treatment, were further cultured on nutrient agar. The radioresistant isolates were identified according to Cowan \& Steel's (1985).

\section{Dose response curve of the selected radioresistant bacterial strains}

Test pieces for each radioresistant bacterial strain were prepared as mentioned before. Triplicate test pieces for each strain were exposed at room temperature to gamma radiation doses suitable for each radioresistant strain. Non irradiated test pieces served as control. After irradiation, the number of surviving colonies was counted and the mean of triplicate plates for the test pieces was reported as cfu $\mathrm{ml}^{-1}$.

The survival curves were constructed by logarithmic plotting of the number of survivors versus the radiation doses in kGy in linear scale.

The $\mathrm{D}_{10}$ value which is the measure for the radiation resistance of the microorganisms was obtained according to Schmidit \& Nank (1960).

\section{Determination of the bioburden of eye make up samples}

The total bacterial counts were determined for eye make up samples representing the different manufacturing companies. One $\mathrm{ml}$ or $\mathrm{g}$ of each sample was mixed with $9 \mathrm{ml}$ sterile dilluent, $0.1 \%$ (w/v) peptone water, containing $0.1 \%$ (v/v) Tween 80 (Behravan et al., 2005). Ten fold serial dilutions were made and aliquots of $0.1 \mathrm{ml}$ were taken from each appropriate dilution and spread on solidified nutrient agar. The plates were incubated at $35 \pm 2{ }^{\circ} \mathrm{C}$ for 4 days. The total bacterial count was determined. The mean of the total bacterial counts for each group of samples representing a manufacturing company (Bioburden) was then recorded.

\section{Calculation of the sterilization doses}

The radiation sterilization dose for each product was calculated based on the average initial count of the contaminating microorganisms (bioburden) on this product and the radiation resistance $\left(D_{10}\right.$ value) of the most radiation resistant contaminant and the sterility assurance level (SAL) required for this product (Christensen et al., 1967 a, b ; Miller \& Berube, 1978 and USPXXI, 1985). 
For determination of the sterilization dose of certain product, the survival curve of the most radiation resistant bacterial strain was used. A parallel curve to that of the radiation resistant microorganisms is drawn starting at initial count equals the average bioburden on the product wanted to be sterilized. The drawn curve is extrapolated to the negative side of the y-axis. For the eye make up preparations $\left(10^{-6}\right)$ is the sterility assurance level. To get the sterilization dose for this product, a parallel line to the $\mathrm{x}$-axis is drawn starting at log cycle (-6) on the negative side of the y-axis until it meets the extrapolated part of the curve, then a parallel line to the $y$-axis is drawn until it meets the $\mathrm{x}$-axis to give the required sterilization dose which realizes the sterility assurance level of one per million $\left(10^{-6}\right)$. This is for straight line survival curves, but if the survival curve of the most radiation resistant microorganism is shouldered, the size of the shoulder was defined by the "intercept" on the $100 \%$ survival axis (quasithreshold dose, Dq). So, (Dq) was added to the determined dose value (Roushdy et al., 1999).

\section{Applicability of radiation sterilization dose}

The calculated radiation sterilization doses for eye make up samples were applied on the most contaminated samples of each individual company. The probability of sample contamination was studied by determination of the viable count on the samples after application of the calculated sterilization doses, as mentioned before.

\section{Results and Discussion}

Although, the use of irradiation decontamination is not very old, it has found its way into many applications. However, there is still much to be investigated to improve the efficiency and to find an ideal procedure which radiation can decontaminate or sterilize items with minimal alteration of their components (Tilquin, 1991; Sainz et al., 1999 and Salih, 2001). Ionizing radiation is very practical in achieving sterility without noticeable changes in the appearance or structure of the irradiated material. Nevertheless, the technology is still limited in use because of unavailability of suitable radiation facilities mainly in some of developing countries (Salih, 2001).

In the present investigation an acceptable level of sterility of eye make up products was attained by the use of $\gamma$-irradiation. The dried preparations of the mixed population of previously isolated bacterial strains from eye make up samples (38 strains of eye shadow, 23 strains of eye mascara and 16 strains of eye liner) representing some individual companies, were used in this study. The isolated radioresistant bacteria after exposure of the mixed populations to gamma irradiation $(2.0-20 \mathrm{kGy})$ were shown in Table 1 . The resistant bacteria were identified as Staphylococcus aureus, Bacillus megaterium and Staphylococcus epidermidis, from eye shadow ; Staphylococcus aureus and Staphylococcus epidermidis from eye mascara and three strains of Bacillus cereus, Staphylococcus epidermidis and Staphylococcus aureus, from eye liner. Those bacterial isolates survived from 5-14, 5-6 and 4-11, kGy, respectively. 
TABLE 1. Evaluation of the radio-resistant microbial strains after exposure of the mixed bacterial population to gamma radiation $(\mathrm{kGy})$.

\begin{tabular}{|c|c|c|c|c|c|c|}
\hline $\begin{array}{l}\text { Eye } \\
\text { make } \\
\text { up }\end{array}$ & Co. & Mixed population & $\begin{array}{l}\text { No. of } \\
\text { strains }\end{array}$ & $\begin{array}{l}\text { Radio- } \\
\text { resistant } \\
\text { strain }\end{array}$ & $\begin{array}{c}\text { Sub } \\
\text { D* }^{*} \\
\text { kGy }\end{array}$ & $\mathbf{D}_{10}$ \\
\hline \multirow{6}{*}{$\begin{array}{c}\text { Eye } \\
\text { shadow }\end{array}$} & A & Staphylococcus aureus & 5 & $\begin{array}{c}\text { Staphylococcus } \\
\text { aureus }\end{array}$ & 6 & 0.9 \\
\hline & $\mathrm{C}$ & $\begin{array}{l}\text { Bacillus megaterium and } \\
\text { Staphylococcus aureus }\end{array}$ & $\begin{array}{l}5 \text { and } \\
5\end{array}$ & $\begin{array}{l}\text { Bacillus } \\
\text { megaterium }\end{array}$ & 14 & 1.7 \\
\hline & $\mathrm{D}$ & $\begin{array}{c}\text { Staphylococcus aureus } \\
\text { and Klebsiella } \\
\text { pneumonia }\end{array}$ & 4,4 & $\begin{array}{c}\text { Staphylococcus } \\
\text { aureus }\end{array}$ & 7 & 0.95 \\
\hline & $\mathrm{E}$ & Staphylococcus aureus & 4 & $\begin{array}{c}\text { Staphylococcus } \\
\text { aureus }\end{array}$ & 6 & 1.0 \\
\hline & $\mathrm{F}$ & $\begin{array}{c}\text { Staphylococcus } \\
\text { epidermidis }\end{array}$ & 5 & $\begin{array}{c}\text { Staphylococcus } \\
\text { epidermidis }\end{array}$ & 5 & 0.7 \\
\hline & G & $\begin{array}{c}\text { Bacillus megaterium } \\
\text { and Staphylococcus } \\
\text { aureus }\end{array}$ & $\begin{array}{c}3 \text { and } \\
3\end{array}$ & $\begin{array}{c}\text { Bacillus } \\
\text { megaterium }\end{array}$ & 13 & 1.8 \\
\hline Total & & -- & 38 & 6 & -- & -- \\
\hline \multirow{5}{*}{$\begin{array}{c}\text { Eye } \\
\text { mascara }\end{array}$} & A & Staphylococcus aureus & 5 & $\begin{array}{c}\text { Staphylococcus } \\
\text { aureus }\end{array}$ & 6 & 1.0 \\
\hline & $\mathrm{H}$ & Staphylococcus aureus & 5 & $\begin{array}{c}\text { Staphylococcus } \\
\text { aureus }\end{array}$ & 6 & 1.0 \\
\hline & I & $\begin{array}{c}\text { Staphylococcus aureus } \\
\text { and Staphylococcus } \\
\text { warneri. }\end{array}$ & $\begin{array}{l}3 \text { and } \\
3\end{array}$ & $\begin{array}{c}\text { Staphylococcus } \\
\text { aureus }\end{array}$ & 6 & 0.9 \\
\hline & $\mathrm{J}$ & Staphylococcus aureus & 3 & $\begin{array}{c}\text { Staphylococcus } \\
\text { aureus }\end{array}$ & 6 & 1.0 \\
\hline & K & $\begin{array}{c}\text { Staphylococcus } \\
\text { epidermidis }\end{array}$ & 4 & $\begin{array}{c}\text { Staphylococcus } \\
\text { epidermidis }\end{array}$ & 5 & 0.8 \\
\hline Total & & & 23 & 5 & -- & -- \\
\hline \multirow{3}{*}{$\begin{array}{l}\text { Eye } \\
\text { liner }\end{array}$} & A & $\begin{array}{l}\text { Bacillus cereus and } \\
\text { Staphylococcus aureus }\end{array}$ & $\begin{array}{l}5 \text { and } \\
5\end{array}$ & $\begin{array}{l}\text { Bacillus } \\
\text { cereus }\end{array}$ & 11 & 1.4 \\
\hline & $\mathrm{H}$ & $\begin{array}{c}\text { Staphylococcus } \\
\text { epidermidis }\end{array}$ & 4 & $\begin{array}{c}\text { Staphylococcus } \\
\text { epidermidis }\end{array}$ & 5 & 0.8 \\
\hline & I & Staphylococcus aureus & 2 & $\begin{array}{c}\text { Staphylococcus } \\
\text { aureus }\end{array}$ & 4 & 0.7 \\
\hline Total & & & 16 & 3 & -- & -- \\
\hline
\end{tabular}

Sub D* kGy: Sub-lethal radiation dose. 
In this respect, Christensen \& Kristensen (1981) isolated radioresistant bacterial strains by exposing dried test pieces containing mixed population of bacteria to gamma irradiation dose levels from 15-50 kGy, While Ashour et al. (1990) found twenty radioresistant bacterial strains survived gamma radiation at 18-20 kGy of which nineteen were identified as Bacillus sp. and one as Micrococcus roseus.

Radiation resistance of microorganisms can be associated with the $\mathrm{D}_{10}$ value, the dose of radiation required to reduce the microbial population by $90 \%$ (Miller \& Berube , 1978).

In the present investigation, the $\mathrm{D}_{10}$ values of the radioresistant bacterial strains (Table 1) were calculated and found to range from $0.7-1.8 \mathrm{kGy}, 0.8-1.0 \mathrm{kGy}$ and 0.7-1.4 kGy for the strains isolated from eye shadow, eye mascara and eye liner samples, respectively. In this field Bochkarev et al. (1978) examined the radiation sensitivity of about 8000 strains of Gram positive microorganisms of dried culture preparations, of which 1500 strains were of Staphylococci; $30 \%$ were found to have $\mathrm{D}_{10}$ value of $0.1-1.0 \mathrm{kGy}$ and the $70 \%$ had $\mathrm{D}_{10}$ value of $2.0 \mathrm{kGy}$.

In another study, Ashour et al. (1993) examined the response of Bacillus sterothermophillus, B. pantothenticus, Bacillus licheniformis, B. coagulans, Bacillus laterospores, Bacillus cereus, Bacillus megaterium, Bacillus pumilis E601 towards gamma radiation and determined the $\mathrm{D}_{10}$ values for these strains ranged from 2.33 to $4.1 \mathrm{kGy}$. On the other hand, Kotiranta et al. (1999) reported that four strains of Bacillus cereus were sensitive to gamma radiation with $\mathrm{D}_{10}$ value $0.4 \mathrm{kGy}$.

The $\mathrm{D}_{10}$ values of Staphylococcus aureus, Bacillus cereus and Bacillus sphaericus were found to be 0.37, 1.0 and 1.4, respectively (Farrag et al., 2000 and El-Fouly et al., 2000). The dose response curve of Bacillus cereus showed exponential response curve and the $\mathrm{D}_{10}$ value was calculated as $0.9 \mathrm{kGy}$ (ElTablawy \& El-Hifnawi, 2009).

On the other hand, Miller \& Berube (1978) examined the effect of radiation on microorganisms and demonstrated two typical dose response curves for microorganisms. Both showed exponential killing, but the one that reflect the response of most organisms showed sensitivity to the radiation. Some organisms are more resistant. The authors were concerned with the resistant organisms than with the sensitive ones.

In the present study, dose response curves of the selected different radioresistant bacterial strains were constructed. The results (Fig. 1 to 8) showed a decrease in the number of survivors with the increase of the radiation dose for the tested radioresistant strains. Gram positive cocci and Bacillus megaterium exhibited exponential rate of death towards gamma radiation and this is manifested by straight line curves (Fig. 1-5 and 7-8). This was in agreement with those reported by other investigators who found that some Bacilli such as $B$.

Egypt. J. Microbiol. 45 (2010) 
megaterium and B. pumilis, also Gram positive cocci had an exponential rate of death (El-Schafei,1982; Ashour et al., 1993; El-Fouly, 2000; Salih, 2001; Bashandy, 2005 and El-Tablawy \& El-Hifnawi, 2009). Only Bacillus cereus (Fig. 6) from eye liner sample exhibited non-exponential rate of death towards gamma irradiation and this is manifested as straight line curve proceeded by an initial shoulder.

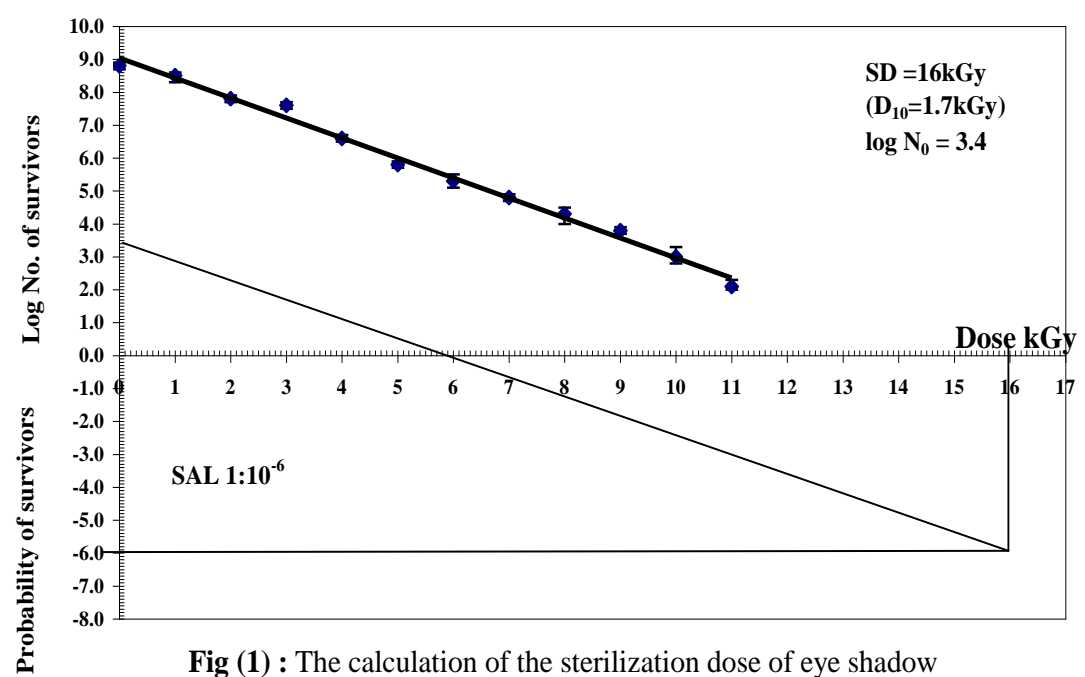

Fig.1. The calculation of the sterilization dose of eye shadow samples Co. (C) using Bacillus megaterium $\left(\mathrm{D}_{10}=1.7 \mathrm{kGy}\right)$ as the most radioresistant isolate.

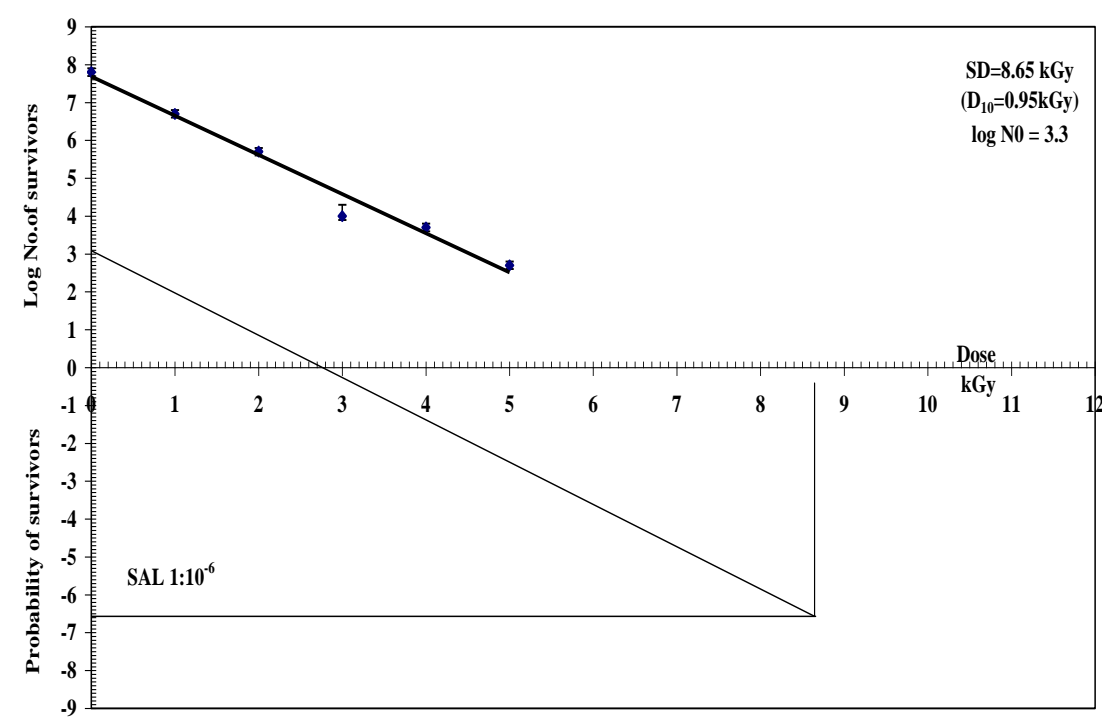

Fig. 2. The calculation of the sterilization dose of eye shadow samples Co. (D) using Staphylococcus aureus $\left(\mathrm{D}_{10}=0.95 \mathrm{kGy}\right)$ as the most radioresistant isolate. 


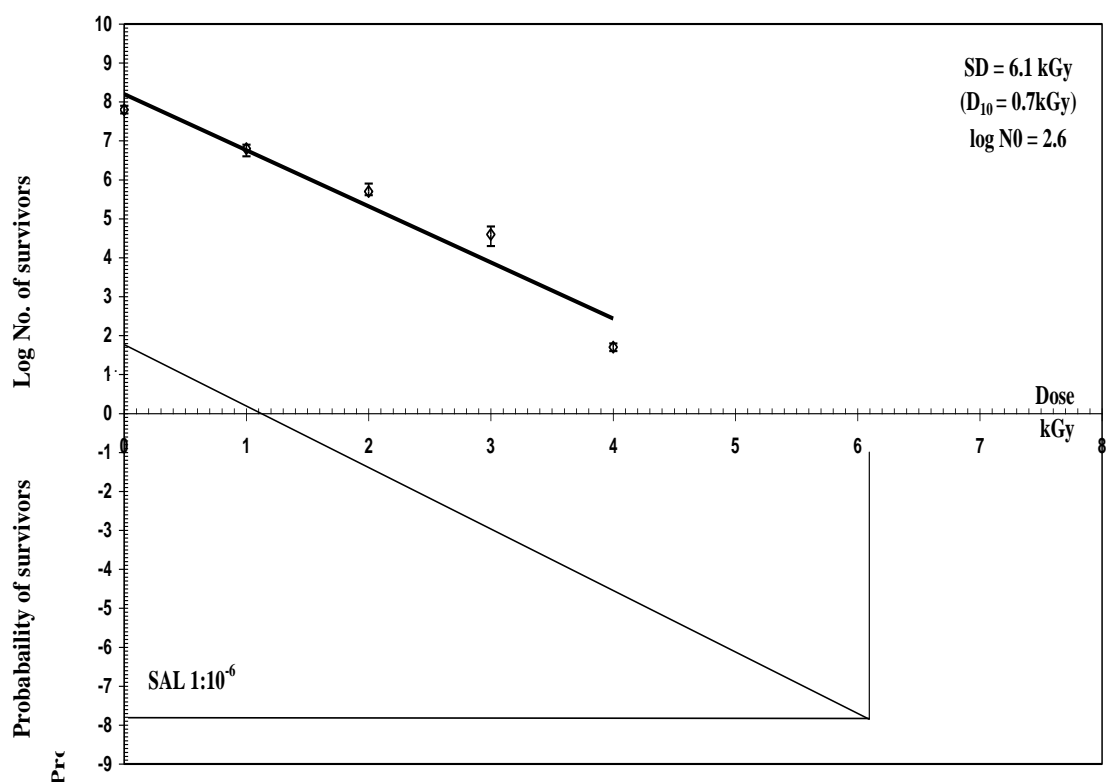

Fig. 3. The calculation of the sterilization dose of eye shadow samples Co. (F) using Staphylococcus epidermidis $\left(D_{10}=0.7 \mathrm{kGy}\right)$ as the most radioresistant isolate.

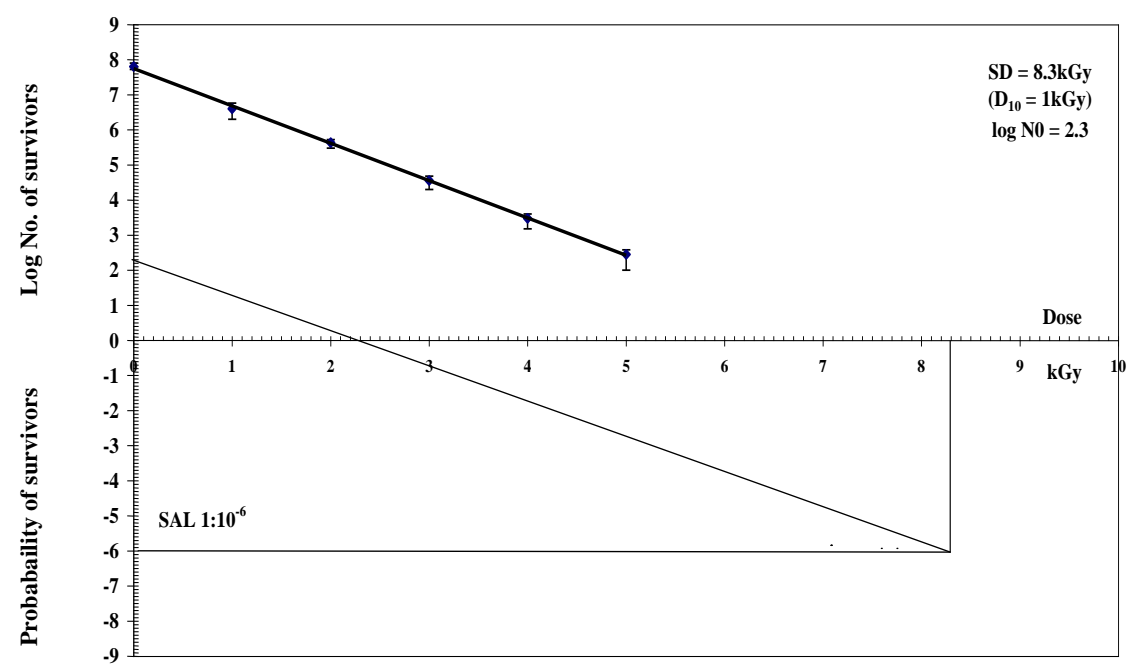

Fig. 4. The sterilization dose calculation of eye mascara samples Co. (A) using Staphylococcus aureus $\left(\mathrm{D}_{10}=1 \mathrm{kGy}\right)$ as the most radioresistant isolate. 


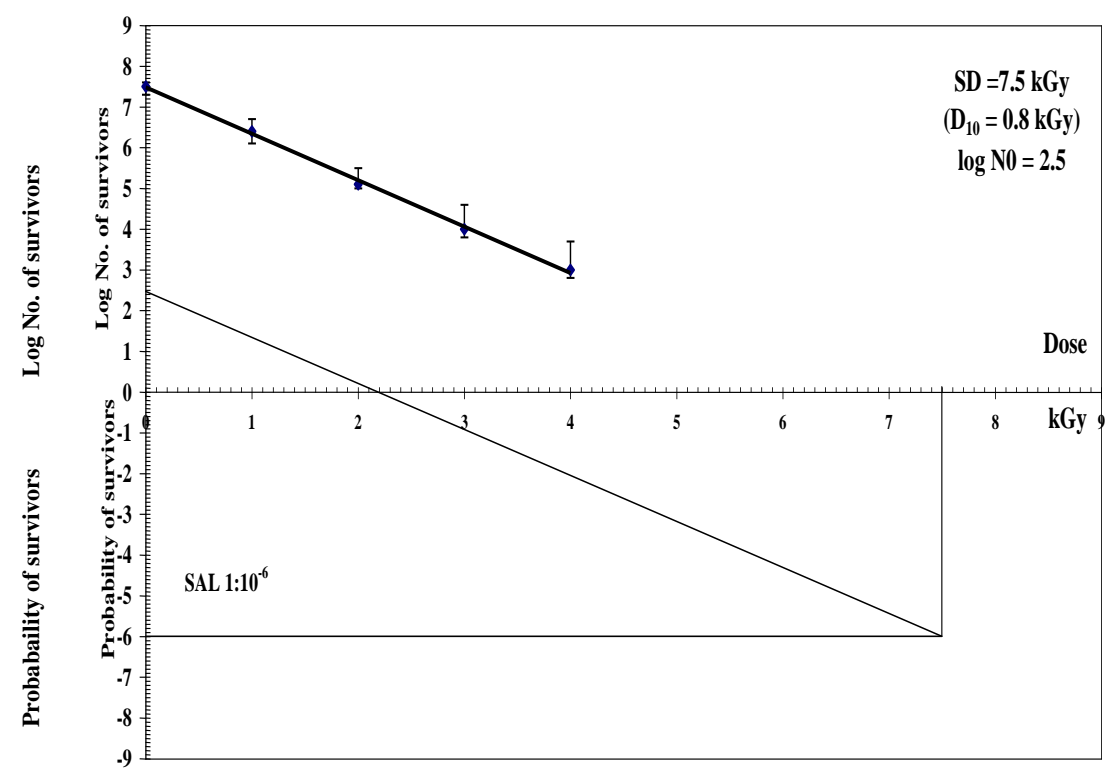

Fig. 5. The sterilization dose calculation of eye mascara samples Co. (K) using Staphylococcus epidermidis $\left(\mathrm{D}_{10}=0.8 \mathrm{kGy}\right)$ as the most radioresistant isolate.

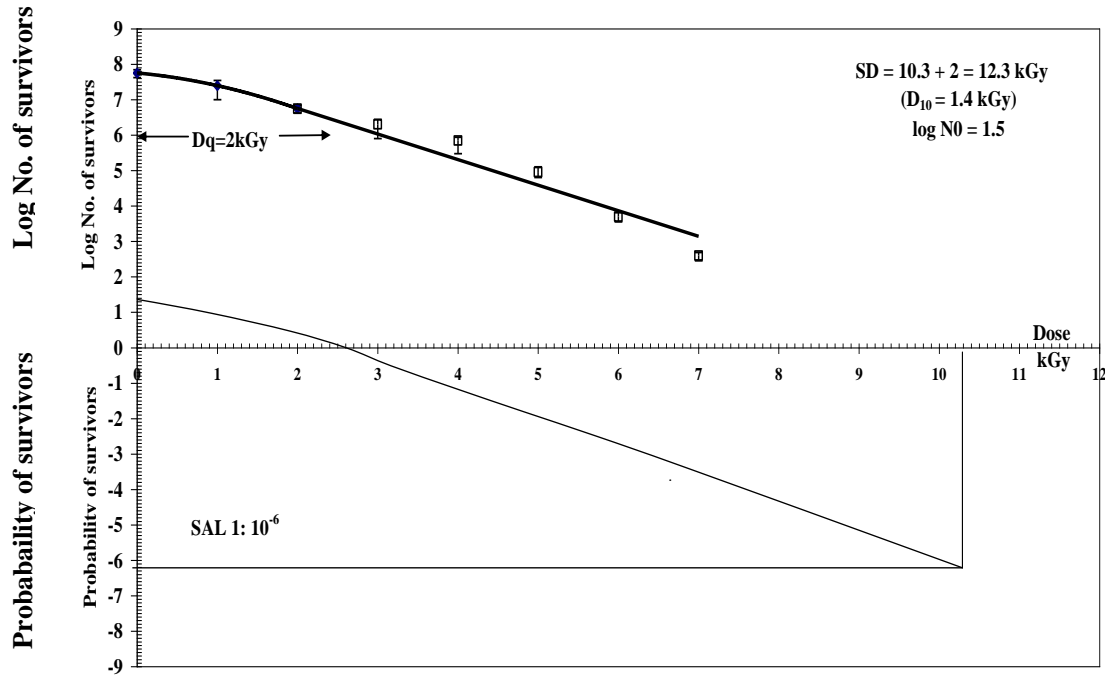

Fig. 6. The calculation of the sterilization dose of eye liner samples Co. (A) using Bacillus cereus $\left(\mathrm{D}_{10}=1.4 \mathrm{kGy}\right)$ as the most radioresistant isolate. 


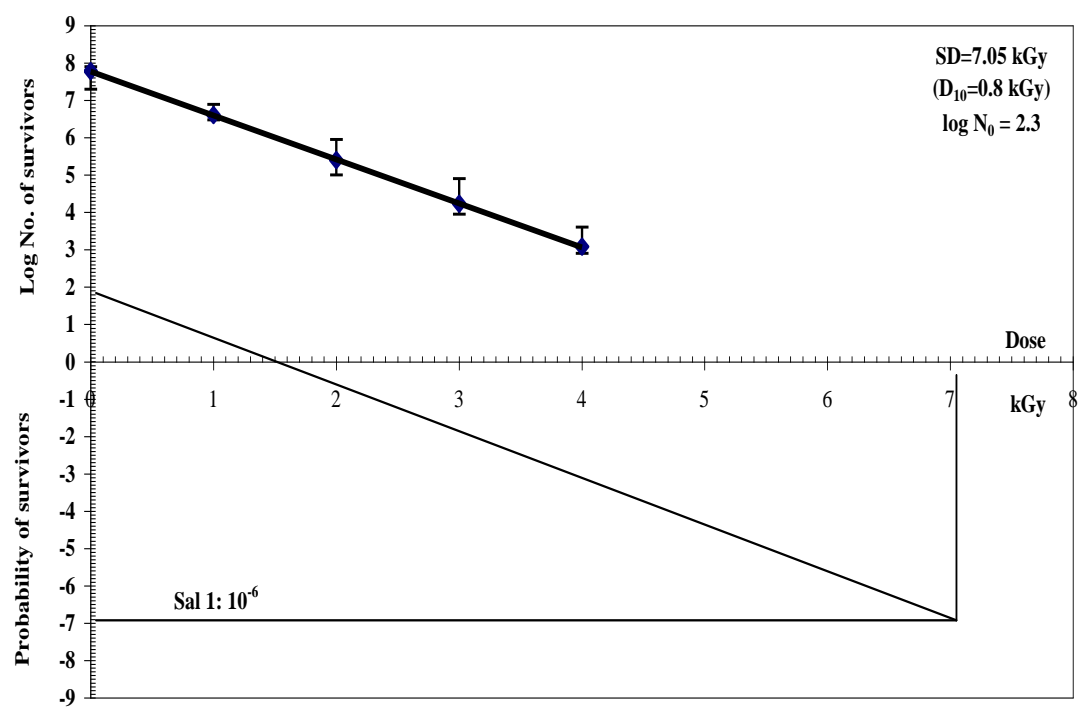

Fig. 7. The calculation of the sterilization dose of eye liner samples of Co. (H) using Staphylococcus epidermidis $\left(D_{10}=0.8 \mathrm{kGy}\right)$ as the most radioresistant isolate.

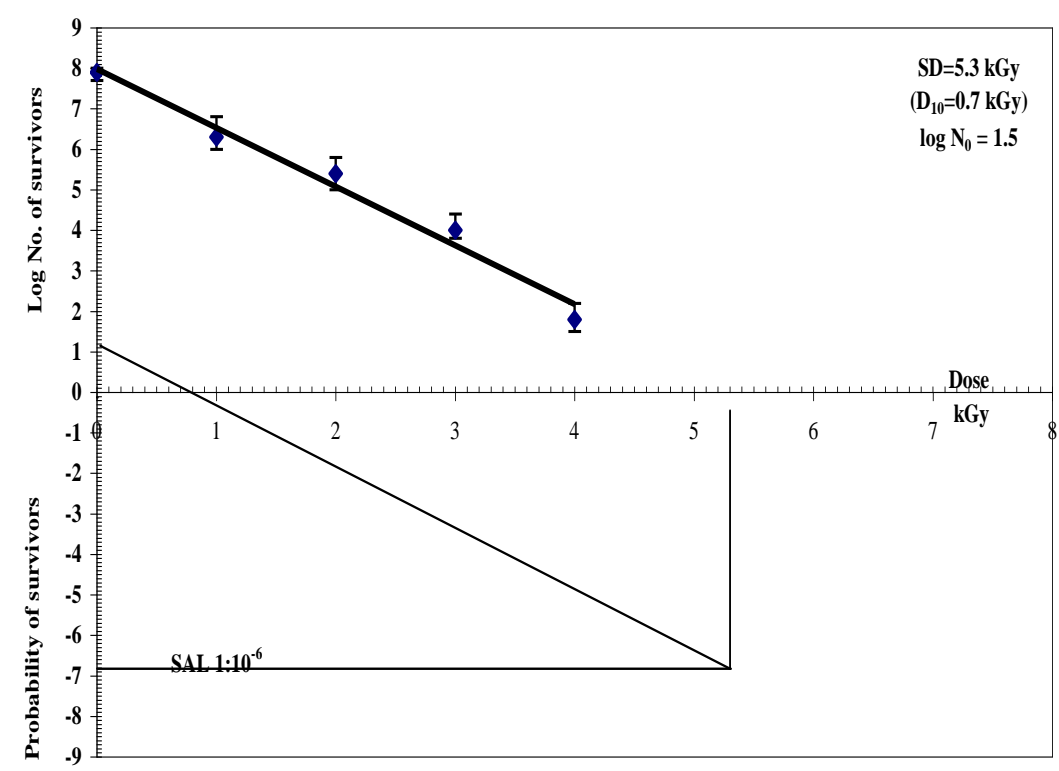

Fig. 8. The calculation of the sterilization dose for eye liner samples of Co. (I) using Staphylococcus aureus $\left(\mathrm{D}_{10}=0.7 \mathrm{kGy}\right)$ as the most radioresistant isolate.

Egypt. J. Microbiol. 45 (2010) 
Similar results were obtained by Ashour et al. (1993) who obtained this response with some Bacillus spores such as B. pantothenticus, B. stearothermophilus, B. circulans, B. coagulans and B. laterosporus and disagree with ElFouly et al. (2000) and Abostate et al. (2006) who found that Bacillus cereus showed an exponential response towards gamma radiation.

The microbiological quality (sterility assurance level or SAL of $10^{-6}$ ) of the finished medical product should be a maximum of one contaminant per one million sterilized products (Christensen et al., 1967 a, b). The United State Pharmacopoeia (1985) stated that the choice of the sterilization dose should be determined by the knowledge of the microbiological bioburden (types and numbers) and the nature of the article to be sterilized.

The dose of ionizing radiation, the microbial contamination load and the degree of radiation resistance of the contaminants are among the factors which determine the efficiency of radiation sterilization (Miller \& Berube, 1978; USPXXI, 1985 and Salih , 2001) .

The sterilization doses in the present study were calculated by applying the survival curves of the radiation resistant isolates (with the highest $\mathrm{D}_{10^{-}}$value). The calculated sterilization doses for eye shadow of Co. (C, D and F) were 16, 8.7 and $15.5 \mathrm{kGy}$, respectively. While the doses for eye mascara of Co. (A and $\mathrm{K}$ ) were 8.3 and $7.5 \mathrm{kGy}$. Also, the sterilization doses for eye liner samples of Co. (A, H and I) were 12.3, 7.05 and $5.3 \mathrm{kGy}$, respectively (Table 2).

The results revealed that the maximum doses obtained in the present investigation are $16 \mathrm{kGy}, 8.3 \mathrm{kGy}$ and $12.3 \mathrm{kGy}$ for sterilization of the studied eye shadow, eye mascara and eye liner, respectively.

The highest sterilization dose obtained for eye liner samples was high compared to those reported by Razem et al. (2003) which was found to be 1.9, 2.2 and $5.3 \mathrm{kGy}$ for eye liner pencils, however, it should be taken into consideration that in the present study liquid eye liner samples were investigated. It is worthy to clarify, in our study that the contaminants were Gram positive bacteria while; the contaminants in the foregoing literature were mainly Gramnegative bacteria and molds. Also, the sterilization doses for powdered eye shadow were higher than eye mascara and eye liner; this is may be attributed to the higher bioburden of the microbial contaminants in the eye shadow samples and their relatively higher microbial resistance to gamma radiations $\left(D_{10^{-}}\right.$ values). 
TABLE 2. Gamma sterilization doses of the eye make up products (different manufacturing companies).

\begin{tabular}{|c|c|c|c|c|c|}
\hline $\begin{array}{c}\text { Eye } \\
\text { make up }\end{array}$ & Company & $\mathbf{N}_{\mathbf{o}}^{(\mathbf{a})}$ & $\log N_{0}$ & Radio-resistant strain & $\begin{array}{l}\mathbf{S D}^{(\mathbf{b})} \\
\mathbf{k G y}\end{array}$ \\
\hline \multirow{6}{*}{$\begin{array}{l}\text { Eye } \\
\text { shadow }\end{array}$} & A & 280 & 2.4 & Staphylococcus aureus & 8.1 \\
\hline & $\mathrm{C}$ & 2400 & 3.4 & Bacillus megaterium & 16 \\
\hline & $\mathrm{D}$ & 2000 & 3.3 & Staphylococcus aureus & 8.65 \\
\hline & $\mathrm{E}$ & 500 & 2.7 & Staphylococcus aureus & 8.7 \\
\hline & $\mathrm{F}$ & 380 & 2.6 & Staphylococcus epidermidis & 6.1 \\
\hline & G & 400 & 2.6 & Bacillus megaterium & 15.5 \\
\hline \multirow{5}{*}{$\begin{array}{l}\text { Eye } \\
\text { mascara }\end{array}$} & A & 210 & 2.3 & Staphylococcus aureus & 8.3 \\
\hline & $\mathrm{H}$ & 128 & 2.1 & Staphylococcus aureus & 8.1 \\
\hline & I & 267 & 2.4 & Staphylococcus aureus & 7.5 \\
\hline & $\mathrm{J}$ & 127 & 2.1 & Staphylococcus aureus & 8.1 \\
\hline & K & 335 & 2.5 & Staphylococcus epidermidis & 7.5 \\
\hline \multirow{3}{*}{ Eye liner } & A & 36 & 1.5 & Bacillus cereus & 12.3 \\
\hline & $\mathrm{H}$ & 200 & 2.3 & Staphylococcus epidermidis & 7.05 \\
\hline & I & 35 & 1.5 & Staphylococcus aureus & 5.3 \\
\hline
\end{tabular}

(a) $\mathrm{N}_{\mathrm{o}}=$ Average bioburden on the samples.

(b) $\mathrm{SD}=$ The calculated sterilization doses.

It is worthy to mention that, the calculated sterilization doses in the present study were applied on the heavily contaminated samples representing each individual company ( 7 eye shadow samples from 6 manufacturing companies, 6 eye mascara samples from 5 companies and 2 eye liner samples from 2 companies). No microbial contaminants were detected after the irradiation process (Table 3).

Egypt. J. Microbiol. 45 (2010) 
TABLE 3. Irradiation of the most heavily contaminated samples with the determined sterilization doses.

\begin{tabular}{|c|c|c|c|c|c|}
\hline \multirow[t]{2}{*}{ Eye make up } & \multirow[t]{2}{*}{ Company } & \multirow[t]{2}{*}{$\begin{array}{c}\text { Samples } \\
\mathrm{No}^{(\text {a) }}\end{array}$} & \multirow[t]{2}{*}{$\begin{array}{c}\text { Dose } \\
\text { (kGy) }\end{array}$} & \multicolumn{2}{|c|}{$\begin{array}{c}\text { Bacterial } \\
\text { contamination count } \\
(\mathbf{c . f . u} / \mathrm{g} \text { or } \mathrm{ml})\end{array}$} \\
\hline & & & & B.ir ${ }^{(b)}$ & A.ir $(\mathrm{c})$ \\
\hline \multirow{6}{*}{ Eye shadow } & A & 3 & 8.1 & $8 \times 10^{2}$ & - \\
\hline & $\mathrm{C}$ & 1 & 16 & $4 \times 10^{3}$ & - \\
\hline & $\mathrm{D}$ & 2 & 8.65 & $5 \times 10^{3}$ & - \\
\hline & E & $\begin{array}{l}1 \\
4\end{array}$ & 8.7 & $\begin{array}{l}6 \times 10^{2} \\
5 \times 10^{2}\end{array}$ & - \\
\hline & $\mathrm{F}$ & 3 & 6.1 & $7 \times 10^{2}$ & - \\
\hline & G & 3 & 15.5 & $6 \times 10^{2}$ & - \\
\hline \multirow{5}{*}{ Eye mascara } & A & 5 & 8.3 & $7 \times 10^{2}$ & - \\
\hline & $\mathrm{H}$ & 2 & 8.1 & $3 \times 10^{2}$ & - \\
\hline & I & $\begin{array}{l}1 \\
2\end{array}$ & 7.5 & $\begin{array}{l}3 \times 10^{2} \\
3 \times 10^{2}\end{array}$ & - \\
\hline & $\mathrm{J}$ & 3 & 8.1 & $3 \times 10^{2}$ & - \\
\hline & K & 1 & 7.5 & $5 \times 10^{2}$ & - \\
\hline \multirow{3}{*}{ Eye liner } & A & 4 & 12.3 & $0.5 \times 10^{2}$ & - \\
\hline & $\mathrm{H}$ & 4 & 7.05 & $3 \times 10^{2}$ & - \\
\hline & K & 3 & 3.25 & - & - \\
\hline
\end{tabular}

(a) : The heavily contaminated samples.

(b) B.,ir: Before irradiation .

(c) A.,ir: After irradiation.

- : No detectable growth.

In this respect, Boegl (1985) reported that the early work on pharmaceuticals and cosmetics relied on the application of $25 \mathrm{kGy}$ dose for sterilization. However, such a high dose was unrealistic as much as it causes wasteful damaging to products. The $25 \mathrm{kGy}$ dose assumed that contamination levels of the presterilized products were high of $10^{3}$.

\section{Conclusion}

The gamma radiation technology can offer the process of sterilization of cosmetics as a mean of achieving a higher standard of microbiological safety limits, decreasing the bioburden on cosmetics and eliminating pathogenic microorganisms. 
The microbial isolates from the eye make up are fortunately, radiation sensitive microbes, which mean that sterilization doses were also lower than those reported in the case of pharmaceuticals. Sterilization doses lower than 25 $\mathrm{kGy}$ are considered as a benefit for the manufacturers who want to use the radiation technology decontamination.

\section{References}

Abostate, M.A.M., Zahran, D.A. and El-Hifnawi, H.N. (2006) Incidence of Bacillus cereus in some meat products and the effect of gamma radiation on its toxin (s). Int. J. Agric. Biol. 8, 1-4.

Ashour, M.S.E., El-Bazza, Z.E. and Mohamed A.S.E. (1993) Study on the stability of resistance of some radio-resistant Bacillus strains. Az. J. Microbiol. 19, 34-48.

Ashour, M.S.E., El-Bazza, Z.E., Helal, A.A.H. and Mohamed, A.S.E. (1990) Selection of radio-resistant bacteria from different sources. Az. J. Microbiol., 7, 272-281.

Bashandy, A.S. (2005) Relationship between dipicolinic acid and survival of some radioresistant Bacilli after exposure to gamma radiation. Arab. J. Nucl. Sci. Appl. 38, 231-237.

Beheravan, J., Bazzaz, F. and Malaekeh, P. (2005) Survey of bacteriological contamination of cosmetic creams in Iran (2000). Int. J. Dermatol. 44, 482-5

Bochkarev, V.V., Pavlov, E.P., Khruhchev, V.G., Sedov, V.V. and Tushov, E.G. (1978) Ecological studies of radiation sensitivity in microorganisms at Some enterprises of medical industry. In: "Sterilization by Ionizing Radiation, II". (Ed: Gaughran and Goudie). pp. 46-49. Multiscience Publication Ltd., Montreal, Canada.

Boegl, W. (1985) "Radiation sterilization or pharmaceuticals: chemical changes and consequences . Radiat Phys. and Chem. 25, 425-435.

Christensen, E.A. and Kristensen, H. (1981) Radiation resistance of microorganisms from air in clean premises. Acta Pathologica et Microbiologica. Scandinavica, B, 89, $293-301$.

Christensen, E.A., Holm, N.W. and Juul, F.A. (1967a) Reports from Denmark "Radiosterilization of Medical products, Pharmaceuticals and Bioproducts, Technical Reports Series No. 72 IAEA, Vienna, p. 60-64.

Christensen, E.A., Holm, N.W. and Juul, F.A. (1967b) Radiosterilization of medical devices and supplies". In: "Radio-sterilization of Medical Products"., IAEA, Vienna, 157, 265-286.

Christensen, E.A. and Holm, N.W. (1964) Inactivation of dried bacteria and bacterial spores by means of ionizing radiation". Acta Pathologica, Microbiologica, Scandanivica, 61, $483-486$. 
Clegg, A. (1988) Control of microbial contamination during manufacture. In: "Microbial Quality Assurance in Pharmaceuticals, Cosmetics and Toiletries ". Bloomfield, S.F., Baird, R., Leak, R.E. and Leech, R. (Ed.), p.49-60 (Chapter 4). Ellis Horwood Ltd., Chichester, UK.

Cowan and Steel's (1985) "Manual for the Identification of Medical Bacteria". Cambridge University Press, London, U.K.

El-Bazza, Z.E., El-Tablawy, S.Y., Hashem, A.E. and Nasser, H.H. (2009) Evaluation of the microbial contamination of some eye make up products before and after use. Biohealth Sci. Bull. 1, 68-75.

EI-Fouly, M.E.Z., Farrag, H.A., El-Bazza, Z.E. and El-Tablawy, Y.M. (2000) Ultrastructure and metabolic changes of certain pathogenic microorganisms after exposure to gamma rays and Nigella sativa fixed oil. AZ. J. Microbiol, 49, 84-99.

El-Schafei, H.A. (1982) A Comparative study on the sterilization of surgical gloves by ionizing radiation and ethylene oxide. M.Sc. Thesis, Faculty of Pharmacy, Cairo Univ., Cairo, Egypt.

El-Tablawy, S.Y. and El-Hifnawi, H.N. (2009) Microbiological contamination of some computer keyboards and mice in National Center for Radiation Research and Technology (NCRRT). World Appl. Sci. J. 6, 162-167.

Farrag, H.A., EI-Bazza, Z.E., EI-Fouly, M.E.Z. and EI-Tablawy, S.Y.M. (2000) Effect of gamma radiation on the bacterial flora of Nigella sativa seeds and on its oil constituents. Acta Pharm. 50, 195-207.

Kotiranta, A.K., Ito, H., Haapasalo, M.P. and Lounatmaa, K. (1999) Radiation sensitivity of Bacillus cereus with and without a crystalline surface protein layer . Microbiol. Lett. 179 , 275.

Miller, W.S. and Berube, R. (1978) Environmental control and bioburden in manufacturing process, In: Sterilization of medical products by ionizing radiation. Proceedings of International Conference, Vienna, Austria, 1977 (Gaughran and Goudie, Ed.), Multiscience Publication Ltd., Montreal, Canada.

Razem, B.K., Branka, M. and Razem, D. (2003) Microbial decontamination of cosmetic raw materials and personal care products by irradiation. Radiat. Phys. and Chem. 66, 309-316

Razem, B.K., Novac, B. and Razem, D. (2001) Microbiological decontamination of botanical raw materials and corresponding pharmaceutical products by irradiation. Rad. Phys. Chem. 62, 261-275.

Roushdy, H.M., EI-Bazza, Z.E., Abu-Shady, M.R., Shihab, A. and El-Hifnawy, H. M.N. (1999) Radiation sterilization of human amniotic membranes applicable in wound treatment and plastic surgery. Egypt. J. Biomed. Sci. 4, 183-194.

Sainz Vidal, D., Rodriquez Napoles, D., Fuentes Estevez, G., Guerra, M., Arcis Soriano, W., Peon Aves, E., Diaz Argota, J.M. and Zaldivar Silva, D. (1999)

Egypt. J. Microbiol. 45 (2010) 
Radiation sterilization of a bi-functional cement formulation of hydroxilapatiteplaster-polymer. Annals of the New York Academy of Sciences, 875, 64-70.

Salih, F.M. (2001) Prediction of growth of Bacillus megaterium spores as affected by Gamma radiation dose and spore load . J. of Applied Microbiology, 91, 176-181.

Schmidit, C.F. and Nank, W.K. (1960) Radiation sterilization of food I. Procedures for the evaluation of the radiation resistance of spores of Clostridium botulinum in food products. Food Research, 25, $321-327$.

Tilquin, B. (1991) Radiation sterilization of drugs. Journal de Pharmacie deBelgique, 46, 396-398.

USPXXI (1985) United States Pharmacopeaeia XXI .

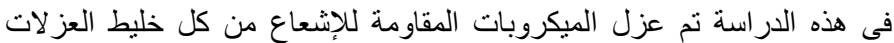

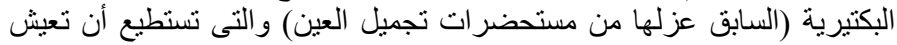

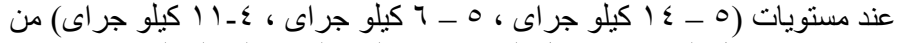

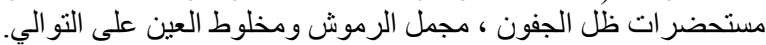

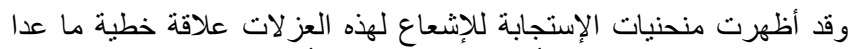

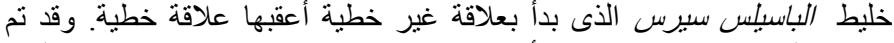

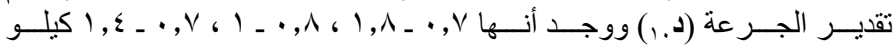

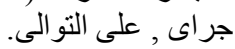

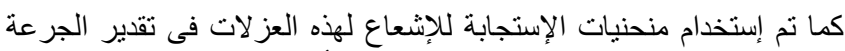

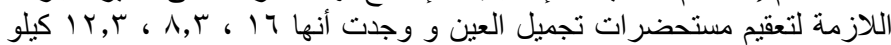
جر اى على التو الى بالنسبة للمستحضر ات التمبل الثلاثة. 